\title{
Problem Traceability in the Innovation of Gender-Responsive Educational Policy
}

\author{
Ismi Dwi Astuti Nurhaeni, Prof.Dr., M.Si. ${ }^{a}$, Yusuf Kurniawan, SS, MA. ${ }^{\text {b }}$, Intan Sani Putri, \\ S.Sos ${ }^{\mathrm{c}}$, and Sudaryanti, Dra, M.Si ${ }^{\mathrm{d}}$ \\ apublic Administration Department, Faculty of Social and Political Sciences, Universitas

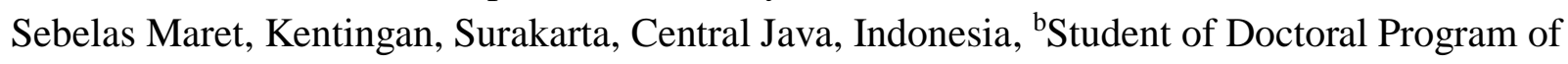 \\ Cultural Studies, Universitas Sebelas Maret, Kentingan, Surakarta, Central Java, Indonesia, \\ ${ }^{\mathrm{c}}$ Public Administration Department, Faculty of Social and Political Sciences, Universitas \\ Sebelas Maret, Kentingan, Surakarta, Central Java, Indonesia dPublic Administration \\ Department, Faculty of Social and Political Sciences, Universitas Sebelas Maret, Kentingan, \\ Surakarta, Central Java, Indonesia \\ aismidwiastuti@staff.uns.ac.id, byusuf@staff.uns.ac.id, 'sani2putri@gmail.com, \\ ${ }^{\mathrm{d}}$ sudaryanti26@gmail.com
}

\begin{abstract}
Gender equality is one of the targets of Sustainable Development Goals and improves human-development quality. According to UNDP (2016) gender disparity in education still exists. It shows that the innovation of gender-responsive educational policy in the form of gender mainstreaming in educational field implemented since 2008 has not succeeded. This article discusses problem traceability in the innovation of gender-responsive educational policy. The aspects cover technical difficulties encountered by the schools in implementing seven keycomponents of gender mainstreaming at school, diversity of target-group behavior and extent of behavior change required. This research was conducted at all 92 junior high schools of Sragen Regency, Indonesia, involving 150 teachers as the respondents who were purposively selected. They are comprised of counseling teachers having participated in gender-responsive school trainings. The data were collected through questionnaires, observation, documentation studies and focus group discussion. To analyze the data NVivo version 11 was utilized for lessening the researchers' subjectivity. The research reveals that problem traceability encountered by the schools are technical difficulties, diversity of the target groups and extent of behavior change required. Although the schools have shortage in human resources understanding gender, institutional difficulties and no guidance on the implementation of the innovation of genderresponsive educational policy, the diverse school elements (teachers, administration staff and students) support the implementation of the policy. The schools expect behavioral change of all school members, i.e. students, teachers, administration staff and parents/society to perform activities supporting the implementation of the policy. It is recommended to assign all school elements to participate in trainings on the implementation of gender at school. In addition, the government's education office should provide standard operational procedure of the implementation of gender-responsive educational policy.
\end{abstract}

Keywords: Gender responsive; Innovation; Educational policy; Problem traceability 


\section{Introduction}

One of the targets of Sustainable Development Goals is gender equality since it improves the quality of human development. In educational field, gender equality should be comprehended as not merely eliminating gender discrimination inherently embedded in the practices of education. Moreover, it also integrates the needs and experiences of both male and female students into all practices of education and therefore makes them able to overcome traditional gender relations through education (Allana et al., 2010).

Achieving gender equality in education is difficult. According to UNDP survey of 2016, gender disparity in educational field still existed. According to Allana et al. (2010) male representation is still higher than that of female and stereotypes of gender roles still persist. Furthermore, Allana et al. (2010) argue that gender differences are still discovered in the learning outcome and subject choices. Ching-Li (2014) finds the practices of gender bias in unequal hidden treatment, school structures, culture, educational policy, access to education, curricula design, teaching and learning activities and student-teacher interaction at schools. It is revealed that the innovation of gender-responsive educational policy in the form of gender mainstreaming in educational field for actualizing gender equality in education has not succeeded.

Gender mainstreaming is a strategy to achieve gender equality through the integration of gender issues in all stages of development. Gender mainstreaming in Indonesia began to be implemented in 2000, meanwhile gender mainstreaming in education is the innovation of gender-responsive education policy implemented in Indonesia since 2008.

Gender integration involves identifying and responding to gender differences and inequalities during every phase of an endeavor-from analysis, planning and design through implementation, monitoring and evaluation. In educational field, this approach influences the process at the level of system reform. Planning and policy development cover gender-specific needs, interests and values of women, men, girls and boys, recognizing that gender differences influence how policies are developed and implemented. In a gender-integrated approach, every policy and program is evaluated based on whether it increases or decreases gender inequality. For example, at the time of curriculum reform, a gender-integrated approach would ensure that textbooks and classroom practices promote gender equitable norms and model of nonviolent behavior towards building the social, emotional, physical and cognitive well-being of all teachers and students (Global Partnership Education, 2006).

Identifying and responding gender differences and inequalities are required in every stage of an endeavor -from analysis, planning and design through the implementation, monitoring and evaluation. The approach influences the process at the level of system reform. Gender-specific needs, interests and values of women, men, girls and boys are taken into account, considering that policies are developed and implemented under the influence of gender differences. Genderintegrated approach examines whether every policy and program is evaluated based on the increase or decrease of gender inequality.

Benchop, De Heas \& Largo-Janssen (in Hsingchen, 2016) argue that there are three reasons why gender mainstreaming is still not successfully implemented. This can be classified 
into three levels, i.e. policy, organization and culture. Promoting gender-responsive educational policy is not based on short-and long-term plan. Moreover, bias and neutral gender treatment becomes the barrier of gender implementation in education (Ching-Li, 2014). Gender-responsive schools' commitment plays an important role in promoting gender-responsive education policy (Marcus \& Page, 2016).

Analysis of the existing education policies is an essential component of the sector analysis. Applying a gender lens can help highlight the achievements of girls' education under the existing policies as well as areas for improvement (Global Partnership Education, 2006). This article discusses problem traceability in the innovation of gender-responsive educational policy. With reference to Mazmanian and Sabatier (1983) this article elaborates four indicators of problem traceability, i.e. (1) technical difficulties, (2) diversity of target group behavior, (3) target group as percentage of the population, and (4) extent of required behavioral change.

\section{Literature Review}

There are several theories about policy implementation, such Grindle's (1990), Mazmanian \& Sabatier's (1983), Meter \& Horn's (1975) models, etc. Of all the theories, only Mazmanian \& Sabatier's theories discusses about problem traceability. This article refers to Mazmanian and Sabatier's theories (1983) stating that the success of policy implementation is influenced by three variables, namely (1) traceability of the problem, (2) the ability of the statute to structure implementation and (3) non-statutory variables affecting implementation. What is meant by traceability is problems encountered by an organization in implementing a policy, comprising of four indicators, i.e. (1) technical difficulties; (2) diversity of target group behavior; (3) percentage of the target group and (4) extent of the required behavioral change. However, in this article the fourth indicator is not used due to the difficulty to determine the number of target group of gender-responsive schools.

\section{Methods}

Sragen was selected due to a number of reasons: (1) the vision of Sragen Regency Government has integrated gender equality and equity, (2) Sragen Regency has conducted trainings on gender-responsive school since 2013, but the Gender-related Development Index (GDI) of Sragen in 2014 was 92.13 and it was considered low compared to that of the other regencies in the Ex-Surakarta Regency (it can be seen in Table 1), (3) there were gender disparities in the Net Enrollment Rate and Gross Enrollment Rate in Junior High School level. 
Table 1: The comparison of Gender-related Development Index (GDI) \& Gender Empowerment Measure (GEM) in Surakarta Regency Year 2014.

\begin{tabular}{|l|l|l|}
\hline Regency/City & GDI & GEM \\
\hline Boyolali & 92,76 & 65,71 \\
\hline Klaten & 95,90 & 59,93 \\
\hline Sukoharjo & 96,39 & 71,94 \\
\hline Wonogiri & 89,87 & 63,34 \\
\hline Karanganyar & 96,08 & 77,00 \\
\hline Sragen & 92,13 & 61,75 \\
\hline Kota Surakarta & 96,48 & 74,93 \\
\hline
\end{tabular}

Source: Kementerian Pemberdayaan Perempuan dan Perlindungan Anak (2015).

The research was carried out at all junior high schools (92 schools) by involving 150 teachers who were purposively selected as the respondents. They are comprised of counseling teachers having participated in the workshops on gender responsive school. The data were collected through questionnaires, observation, documentation studies and focus group discussion. Of the 150 respondents, merely 134 people filled out the questionnaires completely.

In this article the variable of "problem traceability" is divided into three sub-variables, i.e.: (1) technical difficulties; (2) diversity of target group behavior; and (3) extent of the required behavioral change. However, the target group variable as the percentage of the population is not researched due to the difficulty to find all the target groups based on sexes.

\section{Technical Difficulties}

Technical difficulty constitutes a difficulty encountered by the schools in implementing the seven key components of gender mainstreaming at schools. The technical difficulties are classified into seven indicators:

1.1. commitment difficulty of the decision-making officials;

1.2. operationalization difficulty in integrating gender mainstreaming policies into school activities;

1.3. institutional difficulty accommodating the consultation on the implementation of genderresponsive school;

1.4. difficulties on human resources who understand gender;

1.5. unavailability of guidance of the implementation of gender-responsive school;

1.6. difficulty in compiling the disaggregated data on education based on sexes;

1.7. difficulty in obtaining the support from parents and society in implementing genderresponsive school. 


\section{Diversity of target group behavior}

Diversity of target group behavior is the diversity of behavior of students, teachers, administration staff and parents. In this research the diversity of behavior of the target group is classified as follows:

2.1. more than $50 \%$ of students perform activities, which do not support gender equality and equity;

2.2. more than $50 \%$ of teachers perform activities, which do not support the implementation of gender responsive school;

2.3. more than $50 \%$ of administration staff perform activities, which do not support genderresponsive school;

2.4. more than 50\% of parents/society perform activities, which do not support the implementation of gender-responsive school.

\section{Extent of the required behavioral change}

Extent of the required behavioral change is that of the students, teachers, administration staff, parents, and society in integrating gender to their activities. In this research behavioral change is classified into four indicators:

3.1. more than $50 \%$ of students support the implementation of gender-responsive school;

3.2. more than $50 \%$ of teachers integrate gender into teaching-learning process;

3.3. more than $50 \%$ of administration staff support by providing the disaggregated data based on sexes;

3.4. more than $50 \%$ of parents/society support the implementation of gender-responsive school.

Vivo version 11 is utilized to analyze the data for lessening the researchers' subjectivity. There are some stages of NVivo, i.e.: (1) recapitulation of questionnaire result; (2) data input to NVivo software; (3) attainment of the value result to every single question; (4) determination of maximum and minimum scores of each indicators. The determination of maximum and minimum is obtained from the simplification of Likert's five scale to become three scale on the following conditions: (1) agree (resulting from the addition of coverage score of agree and agree very much); (2) neutral (3) disagree (resulting from the addition of coverage value of disagree and disagree very much). The maximum score is obtained from the biggest score of each indicators and the minimum one is attained from the smallest score.

\section{Discussion}

The research result reveals that the schools have difficulties in implementing the innovation of gender-responsive educational policy in the dimensions of technical difficulties, diversity of target group behavior and extent of the required behavioral change. In the dimension of technical difficulty, there are three most-supporting difficulties, i.e.: the lack of human resources understanding gender, institutional difficulties accommodating the consultation on the implementation of gender-responsive school and the unavailability of guidance of the 
implementation of gender-responsive school with coverage score of each are $8.48 \%, 8.24 \%$, and $8.24 \%$ respectively. Meanwhile, the smallest percentage of technical difficulty undergone by most of junior high schools in Sragen in implementing the innovation of gender-responsive educational policy is the difficulty in compiling disaggregated data on education based on sexes with coverage of $4.96 \%$.

Table 2: Coverage of Technical Difficulties

\begin{tabular}{|c|c|c|c|c|c|c|}
\hline \multirow[b]{2}{*}{ Technical Difficulties } & \multicolumn{3}{|c|}{ References } & \multicolumn{3}{|l|}{ Coverage } \\
\hline & Disagree & Neutral & Agree & Disagree & Neutral & Agree \\
\hline 1.1. Commitment & 34 & 12 & 88 & 2.72 & 0.96 & 7.04 \\
\hline 1.2. Policy Operationalization & 29 & 11 & 94 & 2.32 & 0.88 & 7.52 \\
\hline 1.3. Institution & 21 & 10 & 103 & 1.68 & 0.8 & 8.24 \\
\hline 1.4. Human Resource Development & 17 & 11 & 106 & 1.36 & 0.88 & 8.48 \\
\hline 1.5. Guidance & 18 & 13 & 103 & 1.44 & 1.04 & 8.24 \\
\hline 1.6. Disaggregated Data & 56 & 16 & 62 & 4.48 & 1.28 & 4.96 \\
\hline $\begin{array}{l}\text { 1.7. Support from Parents and } \\
\text { Society }\end{array}$ & 40 & 15 & 79 & 3.2 & 1.2 & 6.32 \\
\hline
\end{tabular}

Source: result of data processing of NVivo 11

From the indicator of diversity of target group behavior, it can be concluded that students, teachers and administration staff disagree if they are claimed for not performing activities supporting the innovation of gender-responsive educational policy, with coverage score of $5.28 \%, 5.12 \%$ and $5.04 \%$ respectively. Accordingly, although the target group of the implementation of the innovation of gender-responsive educational policy varies (students, teachers and administration staff), their activities support gender equality and equity. It differs in the diversity of parents/society. The study finds that diversity of parents/society tends to provide less support to the implementation of the innovation of gender-responsive educational policy with coverage score of $4.68 \%$. This means that more than $50 \%$ of parents/society perform activities providing less support to the implementation of the innovation of gender-responsive educational policy. 
Table 3. Coverage of diversity of target group behavior

\begin{tabular}{|c|c|c|c|c|c|c|}
\hline \multirow[b]{2}{*}{ Diversity of target group behavior } & \multicolumn{3}{|c|}{ References } & \multicolumn{3}{|l|}{ Coverage } \\
\hline & Disagree & Neutral & Agree & Disagree & Neutral & Agree \\
\hline $\begin{array}{l}\text { 2.1. More than } 50 \% \text { of students } \\
\text { perform activities providing } \\
\text { less support to gender equality } \\
\text { and equity (Diversity of } \\
\text { Students' Behavior) }\end{array}$ & 66 & 5 & 63 & 5.28 & 0.4 & 5.04 \\
\hline $\begin{array}{l}\text { 2.2. More than } 50 \% \text { of teachers } \\
\text { perform activities providing } \\
\text { less support to the } \\
\text { implementation of gender- } \\
\text { responsive school (Diversity } \\
\text { of Lecturers' Behavior) }\end{array}$ & 64 & 19 & 51 & 5.12 & 1.52 & 4.08 \\
\hline $\begin{array}{l}\text { 2.3. More than } 50 \% \text { of } \\
\text { administration staff perform } \\
\text { activities providing less } \\
\text { support to the implementation } \\
\text { of gender-responsive school } \\
\text { (Diversity of Employees' } \\
\text { Behavior) }\end{array}$ & 63 & 18 & 53 & 5.04 & 1.44 & 4.24 \\
\hline $\begin{array}{l}\text { 2.4. More than 50\% of } \\
\text { parents/society perform } \\
\text { activities providing less } \\
\text { support to the implementation } \\
\text { of gender-responsive school } \\
\text { (Diversity of parents' and } \\
\text { society's behavior) }\end{array}$ & 52 & 23 & 59 & 4.16 & 1.84 & 4.68 \\
\hline
\end{tabular}

Source: result of data processing of NVivo 11

In the indicator of extent of the reuired behavioral change, the respondents state that all school elements (including parents and society) support the implementation of the innovation of gender-responsive educational policy with coverage score of each $9.12 \%$ for students, $8.08 \%$ for teachers, $7.36 \%$ for administration staff and $7.12 \%$ for parents/society. It means that although the schools still have shortage in human resources understanding gender, institutional difficulties in accommodating consultation on the implementation of the innovation of gender-responsive educational policy and no guidance for the implementation of the innovation of genderresponsive educational policy, the respondents expect behavioral change of the school members 
(students, teachers and parents/society) to support the implementation of the innovation of gender-responsive educational policy.

Table 4. Coverage of Extent of the Required Behavioral Change

\begin{tabular}{|l|l|l|l|l|l|l|l|}
\hline \multirow{2}{*}{$\begin{array}{l}\text { Extent of the Required Behavior } \\
\text { Change }\end{array}$} & Disagree & Neutral & Agree & Disagree & Neutral & Agree \\
\cline { 2 - 7 } $\begin{array}{l}\text { 3.1. More than 50\% of students } \\
\text { support the implementation of } \\
\text { gender-responsive school }\end{array}$ & 6 & 14 & 114 & 0.48 & 1.12 & 9.12 \\
\hline $\begin{array}{l}3.2 . \quad \text { More than 50\% of teachers } \\
\text { integrate gender into teaching- } \\
\text { learning process }\end{array}$ & & 17 & 101 & 1.36 & 1.28 & 8.08 \\
\hline $\begin{array}{l}3.3 . \\
\text { More than 50\% of } \\
\text { administration staff provide } \\
\text { aggregated data based on sexes }\end{array}$ & 22 & 20 & 92 & 1.76 & 1.6 & 7.36 \\
\hline $\begin{array}{l}\text { 3.4. More than 50\% of } \\
\text { parents/society support the } \\
\text { implementation of gender- } \\
\text { responsive school }\end{array}$ & & 29 & 89 & 1.28 & 2.32 & 7.12 \\
\hline
\end{tabular}

Source: result of data processing of NVivo 11

\section{Discussion}

\section{Technical Difficulties}

The research result reveals that the indicators of technical difficulties mostly supporting the implementation of the innovation of gender-responsive educational policy is human resources who understand gender. The human resources mentioned in this research refer to teachers conducting teaching-learning process. Based on the focus group discussion with the respondents, it is found that teachers even frequently give ideas showing gender-stereotype and position men higher than women. Teachers' gender stereotype are also shown with their disagreement when there are female students who want to pursue their studies in engineering field. Such teachers' attitude shows an indicator that they don't understand gender equality and equity in term of field of study selection when they want to continue their education to the higher degree. The research result corresponds to Allana, Asad, and Sherali (2010) stating that more than a half of teachers do not understand how gender is implemented in the process of teaching and learning. Johnson (2018) and Aina et al. (2011) describe teachers' unfair behavior to students, which can be seen in the following scenes: (1) teachers give more attention to male students than female students; (2) teachers have closer communication with male students; (3) teachers tend to give more appreciation to male students when they succeed in answering questions correctly; (4) gender bias performed by media (printed and electronic, including the 
internet) towards one's perspective on gender equality and equity; (5) the imbalance between male and female characters in children literature and school text-books.

Moreover, the result of focus group discussion shows that the practice of gender inequality is also performed by parents at home. They tend to give gender-bias task and advise their children to select study program in accordance with their sex. Parents tend to suggest their daughters to select culinary art or secretary department and engineering-based departments to their sons. Thus, the implementation of gender values at home is also still weak. Parents have not taught gender education to their children properly.

This research corresponds to that of in Cambodia for instance; parents merely look at the quality of schools in term of their physical appearance. They don't see that equal-gender education is a norm that should be taught to their children. When children do not have good behavior, parents tend to blame their teachers and schools. Parents assume that whatever the knowledge their children receive from schools will give more advantage to male rather than female students (Booth, 2014).

Gender-bias practice is also performed by students in the forms of intimidation and discrimination. This agrees with the research of Cheng-Li (2014) that found intimidation happening to male students with graceful personality like female. By referring to the findings, teachers, parents and students must understand gender and implement it at school. Their understanding about gender concept will make them develop their ideas, thoughts and innovative learning practices, so that they can change the students' mindset and the school environment to become more gender-responsive. This agrees with what Allana et al. (2010) state that "to minimize these gender issues we need to start changing the mindsets of the younger generation of society as they are those who can bring about further change in society, with their innovative ideas, thoughts and practices."

Accordingly it can be concluded that humans constitute the most contributing factor for the success of educational innovation. Technical difficulties encountered by humans in performing educational innovation make school organizations always adapt to and make innovation as the part of organization sustainability and organization management. Glor (2016), Lyke and Gland (2016) state that organization has to adapt to survive and if it does not adapt, it will not survive.

\section{Diversity of target group behavior}

Another factor of problem traceability contributing to the implementation of the innovation of gender responsive-educational policy is the diversity of target-group behavior particularly students, teachers and parents. All of the target group behaviors are acquired through conditioning. Conditioning occurs through interaction with the environment. The responses to environmental stimuli shape their actions. Aina \& Cameron (2011); Booth (2014); Wahyuni (2015) \& Kagesten et al, 2016) explain that one of the triggering factors of the difficulties of gender implementation at schools is the diversity of behavior of the school elements, which do not support gender equality. The diversity of teachers' behavior is shown with separating the 
boys' and girls' toys, using gender-bias books and posting some posters that are gendersubordinate. The diversity of behavior around the school environment and family can influence students' point of view towards what they think and what they do in their future. Booth (2004); Wahyuni (2015) and Kagesten et al. (2016) state that the root of gender inequality is stereotyped and unfair norms. Individuals are socialized to "how to be boys and girls" in accordance with society norms since they are born. The norms influence the way how teenagers interact and get involved in sexual, reproductive and social practices.

According to March, Smyth, and Mukhopadhyay (2005) the social interaction can be in the forms of (1) relations of cooperation, connection, and mutual support; (2) relation of conflict, separation, and competition; (3) relation of difference and inequality. Gender relation will influence how power is distributed between sexes. They create and reproduce systemic differences in men's and women's positions in a given society. They define the way in which responsibilities and claims are allocated and the way in which each is given a value.

To sum up that diversity of target group behavior influences the success or the failure of an innovation. Robert and Guiliani (2016) ); Khallouk (2018) dan Day (2016) argue that there is a tendency of behavior to against innovation due to negative perception towards the innovation itself. Therefore, organization has to be able to create positive perception of the target group towards the innovation offered, so that their behavioral diversity keeps providing them with positive contribution towards the change offered by the organization.

\section{Extent of the required behavioral change}

The research finds that all the school elements (including parents and society) are expected to support the implementation of the innovation of gender-responsive educational policy through their behavioral change from gender bias to gender responsive. The behavioral change covers students' behavior to appreciate between sexes without intimidation and discrimination, teachers' behavior to integrate gender into teaching-learning process, behavioral change of administration staff supporting the aggregated data education based on sexes and behavioral change of parents/society to implement equal-gender education in families.

However, the weak understanding about gender endorses the schools to conduct gender training to all school elements (teachers, administration staff and parents/society). This will have positive influence such as to make teachers understand more about gender, how gender role should be performed, and how gender itself is implemented in teaching-learning activities. Teachers will be able to understand more about how to analyze their behavior towards their both male and female students. Understanding gender and using gender perspective in the teachinglearning activities can help teachers minimize gender discrimination towards their students. Gender training creates teachers' awareness in analyzing texts and pictures, and considering the impacts towards their students as well. With gender training school policies will simultaneously change to gender perspective, so that principals and teachers will be more responsible. Principals will have more attention to the school's vision and mission, which have not implemented gender 
responsiveness within the schools' environment (Allana, Asad, and Sherali, 2010; Wahyuni, 2015).

Cheng-Li (2014) states that there are many aspects that must be given attention and require mature consideration in implementing gender-perspective policies, for example the principals begin to think over how to put gender education in the schools' vision, mission, and activities. In addition, principals, teachers, school committees in cooperation with education authorities start to design gender-responsive curricula, provide consultation service, and think about the resource appropriateness as a step to implement gender mainstreaming policy. To implement this at schools, education authorities can propose small-scale experimental program and improve it gradually after being revised and corrected. This can achieve superb result and the schools may also use other schools' experiences as references. If education authorities do not "instruct" schools to get involved in gender-equality education but they cover the improved concept in their policy design, they tend to convince schools to change the basic value of gender equality to become real actions within their administrative works. They can apply the changes in the institutional design and perspective to move forward proactively towards gender equality and multiculturalism.

Making students understand about gender can improve their quality. In Tanzania (Marcus and Page, 2016; Aina and Cameron, 2011), it is found that female students who became heads of school organization were able to increase their self-confidence. Female students became more active and self-confident to make report on gender-based violence that they underwent at schools. The female students at schools with male-dominated students have better academic achievement. Aside from improving the students' self-confidence, gender mainstreaming can change the curricula to be gender-responsive, namely by creating critical learning climate and endorsing them to improve their skills. Mentors and counsellors at schools play an important role as a role model, build self-confidence and commitment of females to learn. Along with the teaching improvement, this can become a valuable focus for investment and further evaluation. Such mentors are maybe regular teachers or pastoral staff employed to give certain curriculum.

Overall, it can be concluded that the implementation of gender-responsive educational innovation has positive impact towards the school communities.

\section{Conclusion}

Problem Traceability in the Innovation of Gender-Responsive Educational Policy covers technical difficulty, diversity of target group behavior and extent of the required behavioral change. Technical difficulties mostly supporting the innovation of gender-responsive educational policy are the shortage in human resources who understand gender, institutional difficulty and unavailability of guidance. The diversity of target group behavior, which support the implementation of the innovation of gender-responsive educational policy is the diversity of students' behaviors, teachers and academic staff. Meanwhile, the diversity of behavior of parents/society tend to give less support to the implementation of the innovation of genderresponsive educational policy. In the dimension of desired behavioral change, the respondents 
state that all school elements (including parents and society) support the implementation of the innovation of gender-responsive educational policy.

Accordingly, it can be concluded that although the schools still have shortage in genderenlightened human resources, institutional difficulties still exist, and there is no guidance of the implementation of the innovation of gender-responsive educational policy, the diverse school elements, i.e. teachers, administration staff and students support the implementation of the innovation of gender-responsive educational policy. The schools expect behavioral change of all school elements to perform activities supporting the implementation of the innovation of genderresponsive educational policy. Based on the research finding, it is recommended to conduct trainings on gender implementation at schools to all school elements. In addition, the government's education office should provide Standard Operational Procedure of innovation implementation of gender-responsive educational policy.

\section{References}

Aina, O.E., and Cameron, P.A. (2011). Why does gender matter? Counteracting stereotypes with young children. Journal Dimension of Early Childhood, 39(3), 11-19.

Allana, A., Asad, N., and Sherali, Y. (2010). Gender in academic settings: role of teachers. International Journal of Innovation, Management and Technology, 1(4), 343-348.

Booth, M.N. (2014). Education and gender in contemporary Cambodia. International Journal of Humanities and Social Science, 4(10), 42-50.

Ching-Li, W. (2014). Mainstreaming gender into schools in the Taiwan context. Chinese Education and Society, 47(4), 23-31.

Day, J. (2016). Overcoming 10 barriers to Innovation. Retrieved from https://ideascale.com/overcoming-10-barriers-to-innovation/

Global Partnership for Education. (2006). Guidance for developing gender-responsive education sector plans. New York: United Nations Girls' Education Initiative.

Glor, E.D. 2016. Studying the impact of innovation on organization, organizational population, and organizational communities: A framework for research. The Innovation Journal: The Public Sector Innovation Journal, 19(3), 1-20.

Grindle, M.S. (1980). Politics and policy implementation in the third world. Princeton University, New Jersey: Princeton University Press.

Meter, D.S.V. \& Horn, C.E.V. (1975). The policy implementation process: A conceptual framework. Administration and society.

Hsingchen, Y. (2016). Transforming concepts into practices: mainstreaming gender in higher education. Asian Journal of Women's Studies, 22(4), 329-413.

Johnson, J. 2018. 6 Ways you can promote gender equality in your classroom. Teachthougt: we grow teachers. Retrieved from https://www.teachthought.com/education/6-ways-canpromote-gender-equality-classroom/

Kagesten, A., Gibbs, S., Blum, R.W., Moreau, C., Chandra-Mouli, V., Herbert, A., and Amin, A. 2016. Understanding factors that shape gender attitudes in early adolescence globally: a 
mixed-methods systematic review. Journal US National Library of Medicine National Institutes of Health, 11(6).

Kementerian Pemberdayaan Perempuan dan Perlindungan Anak [The ministry of Women Empowerment and Children Protection]. (2015). Pembangunan manusia berbasis gender. Jakarta: Kementerian Pemberdayaan Perempuan dan Perlindungan Anak.

Khallouk, M. (2018). Obstacles to management innovation in nonprofit organizations: the case of an international nongovernmental organization. Journal of Innovation Economics \& Management.

Lyke, H., and Gland, H. (2016). Overcoming the 5 obstacles to organizational agility. Retrieved from https://www.smartbrief.com/original/2016/11/overcoming-5-obstaclesorganizational-agility

March, C., Smyth, I., \& Mukhopadhyay, M. (2005). A guide to gender-analysis frameworks. Oxford: Oxfam GB.

Marcus, R. and Page, E. (2016). Policy brief: girls' learning and empowerment- the role of school environments. United Nations Girl's Education Initiative.

Mazmanian, Daniel A and Sabatier, Paul A. (1983). Implementation and public policy. USA: Scott, Foresman and Company.

Robert, M., and Guiliani, P. (2016). How to manage the obstacles related to management innovation implementation. Lesson from a complex industrial company. XXVE Conference International de Management Strateque, 30 May- 1 June 2016, 1-23.

United Nation Development Programme. (2016). Human development report 2016: Human development for everyone. New York: United Nation Development Programme.

United Nations Educational, Scientific and Cultural Organizational. (2009). Gender in education network in Asia-Pasific (GENIA) toolkit: Promoting gender equality in education. Bangkok: UNESCO.

Wahyuni, L. (2015). Model pengimplementasian pendidikan karakter berbasis gender dalam pembelajaran Bahasa Indonesia SD. Jurnal Sekolah, 24(1), 69-81. 